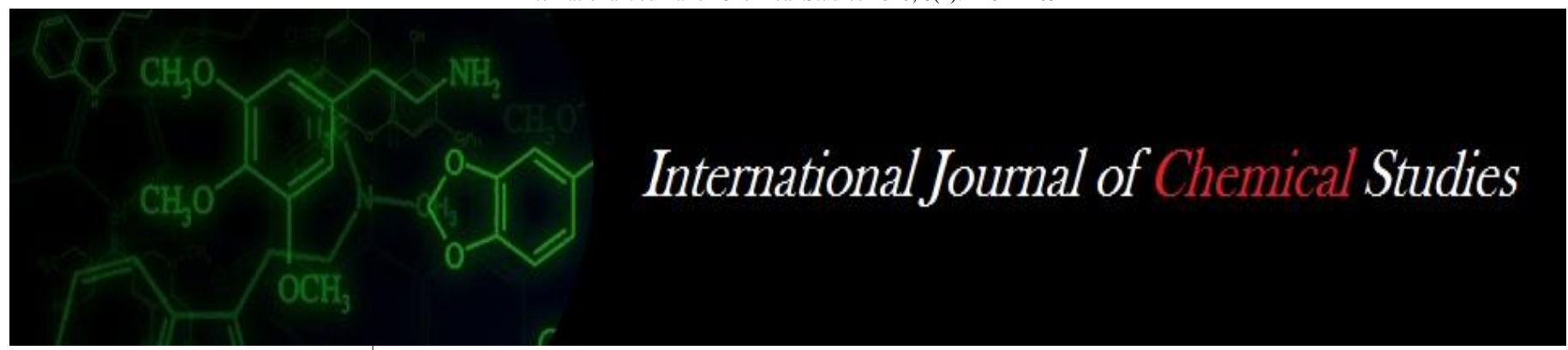

P-ISSN: 2349-8528

E-ISSN: 2321-4902

IJCS 2020; 8(1): 1161-1165

(C) 2020 IJCS

Received: 07-11-2019

Accepted: 09-12-2019

\section{Sharmme Gogoi}

Department of Soil Science and Agricultural Chemistry, Uttar Banga Krishi Viswavidyalaya, Pundibari, Cooch Behar,

West Bengal, India

Dibyendu Mukhopadhyay Department of Soil Science and Agricultural Chemistry, Uttar Banga Krishi Viswavidyalaya, Pundibari, Cooch Behar, West Bengal, India
Corresponding Author: Dibyendu Mukhopadhyay Department of Soil Science and Agricultural Chemistry, Uttar Banga Krishi Viswavidyalaya, Pundibari, Cooch Behar, West Bengal, India

\section{Effect of nutrients on growth and yield attributes of rice in two different methods of cultivation under Terai situation of West Bengal}

\author{
Sharmme Gogoi and Dibyendu Mukhopadhyay
}

DOI: https://doi.org/10.22271/chemi.2020.v8.i1p.8408

\begin{abstract}
An experiment was carried out at the agricultural farm of Uttar Banga Krishi Viswavidyalaya, Pundibari, Cooch Behar during the year 2012-2013 and 2013-2014 to study the effect of zinc on growth and yield attributes of Boro rice, (Cv. Annoda MW-10) at Conventional and SRI (System of Rice intensification) methods. It was observed that grain and straw yield was higher at the SRI method compared to that at the conventional one. The application of NPK @ 75 per cent RDF $(80: 40: 40 \mathrm{~kg} / \mathrm{ha}$ ), biofertilizers $(150 \mathrm{~g}$ per sq.mt) and $25 \mathrm{~kg} \mathrm{ZnSO}_{4}$ per ha resulted significant increase in plant height $(82.76 \mathrm{~cm})$, number of tillers per hill $(25.6)$, panicle length $(26 \mathrm{~cm}), 1000$ grain weight $(29.06 \mathrm{~g})$, straw yield $\left(16.97 \mathrm{t} \mathrm{ha}^{-1}\right)$ and yield of rice $\left(10.07 \mathrm{t} \mathrm{ha}^{-1}\right)$ under SRI method whereas, the same treatment combination gave $9.64 \mathrm{t} / \mathrm{ha}$ grain yield and $16.26 \mathrm{t} \mathrm{ha}^{-1}$ straw yield of rice under the conventional method of cultivation. It could be concluded that application of zinc @ $25 \mathrm{~kg} / \mathrm{ha}$ in addition to the recommended dose of $\mathrm{N}, \mathrm{P}$ and $\mathrm{K}$ along with biofertilizer may be applied for increasing the grain yield of rice.
\end{abstract}

Keywords: Boro rice, yield, zinc, sri, conventional

\section{Introduction}

Zinc $(\mathrm{Zn})$ is considered as one of the essential micronutrients for plants, especially for rice growing under submerged conditions. Although it requires in a very small amount but plays an important role in the growth and development of crop plants, hence, essential for plant growth. Rice is the important cereal crop grown mostly on Indian soils irrespective of soil types and conditions (Naik and Das, 2008) ${ }^{[12]}$. Rice cultivation under non-flooded conditions (aerobic) is an alternative to the conventional rice cultivation system in regions where rainfall and fresh water resources are limited (Ali and Pandey, 2015) ${ }^{[1]}$.

In India, West Bengal is one of the leading states for rice cultivation. Productivity of rice depends upon balance application of nutrients. The soils of West Bengal are relatively poor in micronutrients due to continuous growing of high yielding varieties (Mahata et al., 2012) ${ }^{[10]}$ and for the only incorporation of macronutrients in cropping systems. The deficiencies of micronutrients are of critical importance for sustaining high productivity of rice in India.

Conventional method of rice production has been done under continuously flooded conditions and the hypoxic condition limits the ability of the roots to respire, creates low solubility of some nutrient ions and high solubility of some other nutrient ions and also regulates the ion transport, growth and yield of the crop.

It has become difficult to increase production from traditional rice farming. It needs extra labour and a lot of compost. Farming with modern methods is also expensive in outside inputs. With conventional methods, only by using expensive chemical fertilizers, pesticides and hybrid seed can increase the production. Hence, the SRI method of growing rice with local seed and organic compost, may increase rice production by reducing the demand of water. The better performance of the crop under SRI was the outcome of enhanced growth measured in terms of significantly higher plant height, number of tillers/hill, dry matter accumulation and leaf area index at different growth stages as compare to other methods of planting rice (Bokaria, 2015) ${ }^{[2]}$.

Tzudir and Ghosh (2014) ${ }^{[19]}$ revealed that there were positive and significant effects of organic and inorganic combination of fertilizers on System of rice Intensification (SRI). 
SRI methods had favorable and significant impacts on plant height and panicle length and also showed significant differences in the yield components of grain number in panicles and percent sterility. Kabeya and Shankar (2013) ${ }^{[8]}$ reported that application of $\mathrm{Zn}$ was found to have significant positive influence on growth of rice compared to untreated (zinc) control. Chapagain and Yamaji (2010) ${ }^{[3]}$ also reported that SRI management promoted better root growth, greater number of effective tillers in a hill, longer panicle length, and greater number of filled grains per panicle over conventional management.

Keeping these in perspectives, the present research was undertaken to study the response of zinc on growth and yield attributes of rice under the Terai situation of West Bengal under the two methods of cultivation (i.e., SRI and Conventional).

\section{Materials and Methods}

A field experiment was conducted at the agricultural farm of Uttar Banga Krishi Viswavidyalaya, Pundibari, Cooch Behar during the year 2012-2013 and 2013-2014. The agricultural farm is located within the Terai Agro-climatic zone and its geographic location is $26^{\circ} 39^{\prime} 94.62^{\prime \prime} \mathrm{N}$ latitude and $89^{\circ} 38^{\prime} 94.66^{\prime \prime} \mathrm{E}$ longitude. The elevation of the farm is 43 meters above the mean sea level. The experimental design adopted was RBD (Randomised Block Design) in which there were two methods i.e., i) conventional and ii) SRI and twelve treatments with three-fold replications making a total of 36 (thirty six) plots for each method and the total of 72 (seventy two) plots, each measuring $4 \mathrm{~m} \times 4 \mathrm{~m}$. The variety Annoda (MW-10) was used in both the conventional and SRI methods. The $\mathrm{N}: \mathrm{P}: \mathrm{K}$ as $80: 40: 40 \mathrm{~kg} / \mathrm{ha}$ was considered as the Recommended Dose of Fertilizer (RDF) in the form of Urea, SSP and MOP respectively. The treatments comprised of $100 \% \mathrm{RDF}+10 \mathrm{~kg} \mathrm{Znha}^{-1}\left(\mathrm{~T}_{1}\right), 100 \% \mathrm{RDF}+25 \mathrm{~kg} \mathrm{Znha}^{-1}$ $\left(\mathrm{T}_{2}\right), 100 \% \mathrm{RDF}\left(\mathrm{T}_{3}\right), 75 \% \mathrm{RDF}+$ Biofertilizer (Azotobacter and PSB $)+10 \mathrm{~kg} \mathrm{Znha}{ }^{-1}\left(\mathrm{~T}_{4}\right), 75 \% \mathrm{RDF}+$ Biofertilizer (Azotobacter and PSB) + $25 \mathrm{~kg} \mathrm{Zn} \mathrm{ha}^{-1}\left(\mathrm{~T}_{5}\right), 75 \% \mathrm{RDF}+$ Biofertilizer (Azotobacter and PSB) $\left(\mathrm{T}_{6}\right), 75 \% \mathrm{RDF}+\mathrm{FYM}+$ $10 \mathrm{~kg} \mathrm{Zn} \mathrm{ha}{ }^{-1}\left(\mathrm{~T}_{7}\right), 75 \% \mathrm{RDF}+\mathrm{FYM}+25 \mathrm{~kg} \mathrm{Znha}^{-1}\left(\mathrm{~T}_{8}\right)$, $75 \%$ RDF + FYM ( $\left.\mathrm{T}_{9}\right), 10 \mathrm{~kg} \mathrm{Znha}^{-1}\left(\mathrm{~T}_{10}\right), 25 \mathrm{~kg} \mathrm{Zn} \mathrm{ha}^{-1}\left(\mathrm{~T}_{11}\right)$ and Control $\left(\mathrm{T}_{12}\right)$. The plants of outer row and the extreme ends of the middle rows were excluded to avoid border effect. Five hills were randomly selected from each treatment for recording observations on plant height, total tillers/hill, panicle length and 1000-grain weight (Yadav, 2007) [21]. Grain yield and straw yield, were recorded at harvest. For entire analyses, there were three independent replication for each treatment. Prior to parametric statistical analyses, data were transformed as and when applicable. Transformed data were analyzed by one-way, two-way and or three-way analyses of variance (ANOVAs). Means were separated by post-hoc least significant difference (LSD) test or Fisher's Protected LSD test. The term significant has been used to indicate differences for which $P \leq 0.05$. GenStat Version 11.1.0.1504 (VSN International Ltd., Oxford, UK) was used for statistical analyses (Hsu, 1996) ${ }^{[6]}$.

\section{Results and Discussion \\ Plant height $(\mathbf{c m})$ of rice}

The pooled data ( $1^{\text {st }}$ and $2^{\text {nd }}$ year) pertaining to plant height of rice under conventional method (Table 1) revealed that, significantly higher plant height $(83.52 \mathrm{~cm})$ was recorded in the treatment $\mathrm{T}_{5}$, i.e., 75 percent $\mathrm{RDF}+$ Biofertilizer $+25 \mathrm{~kg}$ $\mathrm{Zn}$ per ha and the lower $(60.92 \mathrm{~cm})$ was in the treatment $\mathrm{T}_{12}$ (control). In SRI method (Table 2), at the treatment $\mathrm{T}_{5}$, the maximum plant height $(82.76 \mathrm{~cm})$ was observed compared to the rest of the treatments. (Table 2). The highest plant height in treatment receiving 75 percent $\mathrm{RDF}+$ Biofertilizer $+25 \mathrm{~kg}$ $\mathrm{Zn}$ per ha was because of the continuous supply of nutrients throughout its growth stage from biofertilizers. Singh et al. (2013) ${ }^{[14]}$ reported that growth, i.e., plant height of rice increased significantly due to the system of rice intensification (SRI) practices as compared to conventional method. The plant height was progressively increased with advancement of the age of crop reported by Dwivedi et al. $(2015)^{[5]}$.

\section{Number of leaves per hill}

The maximum number of leaves per hill (127.96 and 128.90) was observed in the application of 75 percent RDF + Biofertilizer $+25 \mathrm{~kg} \mathrm{Zn}$ per ha $\left(\mathrm{T}_{5}\right)$ in both the methods of cultivation, i.e., Conventional and SRI (Table 1 and Table 2) methods respectively. Kabeya and Shankar (2013) ${ }^{[8]}$ reported that application of $\mathrm{Zn}$ was found to have a significant positive influence on growth of rice in comparison to non-application of zinc as nutrient in soils.

\section{Number of tillers per hill}

The number of tillers per hill in conventional method varied from 9.53 to 25.07 (Table 1) whereas, in SRI method it varied from 10.75 to 25.60 (Table 2). However, the SRI method of cultivation had higher number of tillers per hill (25.60) compared to conventional method (25.07). Rice seedlings when planted earlier need to be provided enough space to express their full potential in terms of growth of leaves, tillers and roots. Enough space, along with other favorable conditions, allows the plants' roots to grow profusely both vertically in deeper parts of the soil and horizontally to cover a larger area, and when roots are spread to a large volume of soil, they tap more nutrients, which results in the development of larger plants with larger number of tillers. The similar findings was reported by Mohanty et al. (2014) ${ }^{[11]}$ in SRI method, where, the yield attributes like plant height, effective tillers per hill, panicle length, number of grains per panicle and test weight were significantly higher as compared to traditional random planting (TRP) method. The hills under SRI had nearly double the number of tillers per plant than Traditional flooding (TF) hills but there was no significant difference in tillers per unit area reported by Thakur et al. (2010) ${ }^{[17]}$.

\section{Panicle length (cm)}

The application of 75 percent RDF along with biofertilizer and $25 \mathrm{~kg}$ of $\mathrm{Zn}$ as zinc sulphate in $\mathrm{T}_{5}$ recorded higher panicle length of $26.75 \mathrm{~cm}$ and $26.00 \mathrm{~cm}$ in conventional (Table 1) and SRI (Table 2) method of cultivation respectively. Prabha et al. (2011) ${ }^{[13]}$ reported that SRI produced significantly highest number of tillers, panicle length, grain yield compared to conventional method.

\section{Number of panicle per plant}

The number of panicles per plant was maximum in $T_{5}$ in both the methods of cultivation (Table 1 and Table 2). The application of 100 percent RDF $+25 \mathrm{~kg} \mathrm{Zn}$ per ha in treatment $T_{2}$ was found to be the second best treatment for panicle number per plant of 13.75 (Table 1) and 14.08 (Table 2) at conventional and SRI method respectively. 


\section{Grains per plant}

The significantly higher grains per plant was noticed in SRI method (861.50) than that of the conventional method (802.34) in the treatment $\mathrm{T}_{5}$ in both the methods of cultivation. Sridevi and Chellamuthu (2012) ${ }^{[15]}$ reported that the SRI method profoundly enhanced the growth and nutrient uptakes which in turn improved the yield attributes of rice. Singh et al. (2013) ${ }^{[14]}$ also reported that the number of grains per panicle was significantly higher as compared to conventional method.

\section{0-grain weight (g)}

The 1000-grain weight of rice $(28.54 \mathrm{~g})$ in treatment $\mathrm{T}_{5}$ (Table 1) in conventional method, was somewhat less than the SRI method (29.06 g) was found in the same treatment (Table 2). The increased plant spacing considerably resulted in vigorous plant growth and caused a significant increase in 1000 grain weight (Thawait et al., 2014) ${ }^{[18]}$.

\section{Grain yield $\left(\mathrm{t} \mathrm{ha}^{-1}\right)$ of rice}

The effect of treatments had significant influence on grain yield of rice. Similar observation was recorded (Thakur et al., 2019) ${ }^{[16]}$ on boro rice at different combinations of nutrients under Terai situation of West Bengal. The change in grain yield from 4.36 to $9.64 \mathrm{t} \mathrm{ha}^{-1}$ in conventional method (Table 1) and from 4.74 to 10.07 tha $^{-1}$ in SRI method (Table 2) was observed. However, the application of 75 percent RDF + Biofertilizer $+25 \mathrm{~kg} \mathrm{Zn}$ per ha in treatment $\left(\mathrm{T}_{5}\right)$ was observed to be the best treatment in both the methods of cultivation and the least was in the untreated control. This might be due to the azotobacter which helps in improving the plant growth, increase the nitrogen in soil through nitrogen fixation by utilizing carbon for its metabolism and the PSB could increase the uptake of $\mathrm{P}$ by the plants, thus helps in increasing the crop yield (Jnawali et al., 2015) ${ }^{[7]}$. The SRI method had higher grain yield in comparison to that of conventional method (Fig. 1). The use of young seedlings, addition of an organic manures, wider spacing and greater aeration from intermittent irrigation might have produced high yields under SRI method, as was reported by Dass and Dhar (2014) ${ }^{[4]}$. Similarly, Wijebandara et al. (2011) ${ }^{[20]}$ reported that the highest grain yield was found under the SRI method of cultivation with $75 \% \mathrm{RDF}+$ biofertilizer $+25 \mathrm{~kg} \mathrm{ha}^{-1} \mathrm{ZnSO}_{4}$.
The grain yield at conventional method was found relatively lower than the yield under the SRI method. This might be due to the lower number of filled grains per panicle, lower number of grains per panicle and panicle length. Similar finding was reported by Singh et al. (2013) ${ }^{[14]}$. The maximum grain yield of rice was achieved by the application of $20 \mathrm{~kg} \mathrm{ZnSO}_{4} \mathrm{ha}^{-1}$ with recommended NPK as compared to the control, which was reported by Keram et al. (2012) ${ }^{[9]}$.

\section{Straw yield ( $\left.\mathrm{t} \mathrm{ha}^{-1}\right)$}

The treatment $\mathrm{T}_{5}$ receiving 75 percent of $\mathrm{RDF}+$ Biofertilizer $+25 \mathrm{~kg} \mathrm{Zn}$ per ha had higher straw yield in conventional and SRI methods of cultivation (Table 1 and Table 2) and the lower (8.87 $\mathrm{t} \mathrm{ha}^{-1}$ and $9.25 \mathrm{t} \mathrm{ha}^{-1}$ ) was in the untreated plot $\left(\mathrm{T}_{12}\right)$. The application of 75 percent of RDF + Biofertilizer + $25 \mathrm{~kg} \mathrm{ZnSO}_{4} \mathrm{ha}^{-1}$ had straw yield of $16.26 \mathrm{t} \mathrm{ha}^{-1}$ and $16.97 \mathrm{t}$ $\mathrm{ha}^{-1}$ in conventional and SRI methods of cultivation respectively. The differences in straw yield between SRI method and conventional method may be related to the variations in number of tillers, leaf area and total dry matter production in plant at the fertilizer levels. The per cent increase in the straw yield by 12 days old seedlings (SRI) was 21.56 per cent over 25 days old seedlings i.e., Conventional method (Thawait et al. 2014) ${ }^{[18]}$.

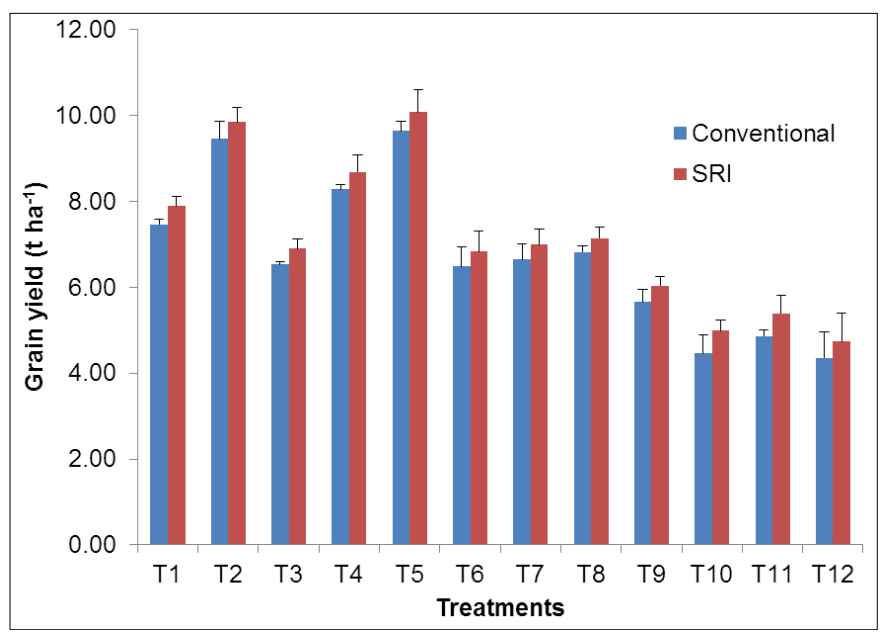

Fig 1: Effect of treatments on grain yield of rice under conventional and SRI methods ofcultivation. The error bar indicates the standard deviation at $5 \%$ level of significance

Table 1: Effect of treatments on growth and yield attributes of rice under conventional method

\begin{tabular}{|c|c|c|c|c|c|c|c|c|c|}
\hline \multirow[b]{2}{*}{ Treatments } & \multicolumn{9}{|c|}{ Conventional (pooled data) } \\
\hline & $\begin{array}{c}\text { Plant height } \\
\text { (cm) }\end{array}$ & $\begin{array}{l}\text { Number of } \\
\text { leaves hill- }\end{array}$ & $\begin{array}{l}\text { Number of } \\
\text { tillers hill }^{-1}\end{array}$ & $\begin{array}{c}\text { Panicle length } \\
(\mathrm{cm})\end{array}$ & $\begin{array}{c}\text { No. of } \\
\text { Panicle/plant }\end{array}$ & $\begin{array}{c}\text { Grains/pla } \\
\text { nt }\end{array}$ & $\begin{array}{l}1000 \text { grain } \\
\text { weight }(\mathrm{g})\end{array}$ & $\begin{array}{c}\text { Grain yield } \\
\left(\text { tha }^{-1}\right)\end{array}$ & $\begin{array}{c}\text { Straw yield } \\
\left(\text { tha }^{-1}\right)\end{array}$ \\
\hline $\mathrm{T}_{1}$ & $76.02 \mathrm{de}$ & $124.10 \mathrm{fg}$ & $23.80 \mathrm{c}$ & $22.42 \mathrm{fgh}$ & $11.58 \mathrm{ef}$ & $717.25 \mathrm{ef}$ & $27.60 \mathrm{ef}$ & $7.47 \mathrm{ef}$ & $13.09 \mathrm{gh}$ \\
\hline $\mathrm{T}_{2}$ & $81.67 \mathrm{fg}$ & $126.11 \mathrm{gh}$ & $24.62 \mathrm{c}$ & $24.00 \mathrm{~h}$ & $13.75 \mathrm{gh}$ & 749.34ef & $27.80 f$ & $9.45 \mathrm{~g}$ & 15.28 \\
\hline $\mathrm{T}_{3}$ & $74.92 \mathrm{~d}$ & $119.31 \mathrm{e}$ & $19.92 \mathrm{~b}$ & $19.67 \mathrm{de}$ & $10.09 \mathrm{cde}$ & $574.34 \mathrm{~cd}$ & $25.40 \mathrm{~cd}$ & $6.54 \mathrm{~cd}$ & $12.10 \mathrm{ef}$ \\
\hline $\mathrm{T}_{4}$ & $78.93 \mathrm{ef}$ & $124.72 \mathrm{~g}$ & $24.20 \mathrm{c}$ & $22.50 \mathrm{gh}$ & $12.25 \mathrm{fg}$ & 743.17ef & $27.67 f$ & $8.28 \mathrm{f}$ & $13.41 \mathrm{~h}$ \\
\hline $\mathrm{T}_{5}$ & $83.52 \mathrm{~g}$ & $127.96 \mathrm{~h}$ & $25.07 \mathrm{c}$ & 26.75 & $15.08 \mathrm{~h}$ & $802.34 f$ & $28.54 \mathrm{f}$ & $9.64 \mathrm{~g}$ & 16.26 \\
\hline $\mathrm{T}_{6}$ & $74.43 \mathrm{~cd}$ & $118.26 \mathrm{de}$ & $19.51 \mathrm{~b}$ & $19.50 \mathrm{de}$ & $9.00 \mathrm{bcd}$ & $528.17 \mathrm{bc}$ & $24.97 \mathrm{~cd}$ & $6.49 \mathrm{~cd}$ & $11.47 \mathrm{de}$ \\
\hline $\mathrm{T}_{7}$ & $76.79 \mathrm{~d}$ & $122.13 \mathrm{f}$ & $20.26 \mathrm{~b}$ & $20.67 \mathrm{ef}$ & $10.34 \mathrm{de}$ & 659.84de & 26.04de & $6.65 \mathrm{de}$ & $12.08 \mathrm{ef}$ \\
\hline $\mathrm{T}_{8}$ & $76.62 \mathrm{de}$ & $123.69 \mathrm{fg}$ & $21.05 \mathrm{~b}$ & $21.75 \mathrm{fg}$ & $11.09 \mathrm{ef}$ & $652.17 \mathrm{de}$ & $27.27 \mathrm{ef}$ & $6.82 \mathrm{de}$ & $12.42 \mathrm{fg}$ \\
\hline $\mathrm{T}_{9}$ & $72.00 \mathrm{c}$ & $116.70 \mathrm{~cd}$ & $17.01 \mathrm{a}$ & $18.50 \mathrm{~cd}$ & $8.59 b c$ & $544.33 b c$ & $24.38 b c$ & $5.66 \mathrm{bc}$ & $10.87 \mathrm{~cd}$ \\
\hline $\mathrm{T}_{10}$ & $64.67 \mathrm{~b}$ & $112.91 \mathrm{ab}$ & 13.18 & $16.67 \mathrm{ab}$ & 7.42ab & $463.50 \mathrm{~b}$ & $22.53 \mathrm{a}$ & $4.46 a$ & $10.03 \mathrm{~b}$ \\
\hline $\mathrm{T}_{11}$ & $66.79 \mathrm{~b}$ & $114.53 b c$ & $15.75 \mathrm{a}$ & $17.25 b c$ & $8.42 b c$ & $487.17 b c$ & $23.04 \mathrm{ab}$ & $4.86 \mathrm{ab}$ & $10.40 \mathrm{bc}$ \\
\hline $\mathrm{T}_{12}$ & $60.92 a$ & $111.01 \mathrm{a}$ & 9.53 & $15.00 \mathrm{a}$ & $6.17 \mathrm{a}$ & $347.67 \mathrm{a}$ & $21.76 \mathrm{a}$ & $4.36 \mathrm{a}$ & $8.87 \mathrm{a}$ \\
\hline \multicolumn{10}{|c|}{ Treatment } \\
\hline $\mathrm{SE}( \pm)$ & 1.02 & 0.87 & 0.61 & 0.62 & 0.61 & 35.36 & 0.55 & 0.32 & 0.27 \\
\hline $\operatorname{LSD}(P=0.05)$ & 2.91 & 2.47 & 1.74 & 1.76 & 1.74 & 100.65 & 1.57 & 0.91 & 0.76 \\
\hline \multicolumn{10}{|c|}{ Practice } \\
\hline $\mathrm{SE}( \pm)$ & 0.42 & 0.35 & 0.25 & 0.25 & 0.25 & 14.43 & 0.23 & 0.13 & 0.11 \\
\hline
\end{tabular}




\begin{tabular}{|l|c|c|c|c|c|c|c|c|c|c|}
\hline LSD $(P=0.05)$ & 1.23 & NS & NS & 0.72 & NS & NS & 0.68 & 0.40 & 0.31 \\
\hline \multicolumn{8}{|c|}{ Treatment X Practice } \\
\hline SE $( \pm)$ & 1.45 & 1.23 & 0.87 & 0.87 & 0.87 & 50.00 & 0.78 & 0.45 & 0.38 \\
\hline LSD $(P=0.05)$ & NS & NS & NS & NS & NS & NS & NS & NS & NS \\
\hline
\end{tabular}

Means with common letters are not significantly different at $P \leq 0.05$, according to Fisher's Protected Least Significant Difference (LSD) test using the algorithm of Studentized range test

Table 2: Effect of treatments on growth and yield attributes of rice under SRI method

\begin{tabular}{|c|c|c|c|c|c|c|c|c|c|}
\hline \multirow[b]{2}{*}{ Treatments } & \multicolumn{9}{|c|}{ SRI (pooled data) } \\
\hline & \begin{tabular}{|c|}
$\begin{array}{c}\text { Plant height } \\
(\mathrm{cm})\end{array}$ \\
\end{tabular} & $\begin{array}{l}\text { Number of } \\
\text { leaves hill- }^{-1}\end{array}$ & \begin{tabular}{|l|} 
Number of \\
tillers hill $^{-1}$
\end{tabular} & $\begin{array}{c}\text { Panicle } \\
\text { length }(\mathrm{cm})\end{array}$ & \begin{tabular}{|c|} 
No. of \\
Panicle/plant
\end{tabular} & Grains/plant & $\begin{array}{l}1000 \text { grain } \\
\text { weight }(g)\end{array}$ & $\begin{array}{c}\text { Grain yield } \\
\left(\text { tha }^{-1}\right)\end{array}$ & $\begin{array}{c}\text { Straw yield } \\
\left(\text { tha }^{-1}\right)\end{array}$ \\
\hline $\mathrm{T}_{1}$ & $77.21 \mathrm{e}$ & $125.26 \mathrm{f}$ & $24.72 \mathrm{c}$ & $22.92 \mathrm{gh}$ & $11.92 \mathrm{ef}$ & 758.92def & $28.10 \mathrm{fg}$ & 7.89de & $13.40 \mathrm{e}$ \\
\hline $\mathrm{T}_{2}$ & $81.09 \mathrm{fg}$ & $127.51 \mathrm{gh}$ & $25.24 \mathrm{c}$ & $24.58 \mathrm{hi}$ & $14.08 \mathrm{gh}$ & $774.33 \mathrm{ef}$ & $28.34 \mathrm{~g}$ & $9.85 \mathrm{fg}$ & 15.69 \\
\hline $\mathrm{T}_{3}$ & $75.36 \mathrm{cde}$ & $120.02 \mathrm{~d}$ & $20.67 \mathrm{~b}$ & $21.00 \mathrm{ef}$ & $10.34 \mathrm{cde}$ & $632.67 \mathrm{~cd}$ & $26.07 \mathrm{de}$ & $6.90 \mathrm{~cd}$ & $12.55 \mathrm{~d}$ \\
\hline $\mathrm{T}_{4}$ & $79.54 \mathrm{f}$ & $125.65 \mathrm{fg}$ & $24.97 \mathrm{c}$ & $22.92 \mathrm{gh}$ & $12.58 \mathrm{fg}$ & 778.84ef & $28.20 \mathrm{~g}$ & $8.69 \mathrm{ef}$ & 14.01 \\
\hline $\mathrm{T}_{5}$ & $82.76 \mathrm{~g}$ & $128.90 \mathrm{~h}$ & $25.60 \mathrm{c}$ & $26.00 \mathrm{i}$ & $15.50 \mathrm{~h}$ & $861.50 \mathrm{f}$ & $29.06 \mathrm{~g}$ & $10.07 \mathrm{~g}$ & 16.97 \\
\hline $\mathrm{T}_{6}$ & $74.84 \mathrm{~cd}$ & $119.10 \mathrm{~cd}$ & $20.10 \mathrm{~b}$ & 20.34 de & $9.59 \mathrm{bcd}$ & $553.17 \mathrm{bc}$ & $25.47 \mathrm{de}$ & $6.84 \mathrm{~cd}$ & $11.87 \mathrm{c}$ \\
\hline $\mathrm{T}_{7}$ & $75.67 \mathrm{de}$ & $122.91 \mathrm{e}$ & $20.92 b$ & $22.08 \mathrm{fg}$ & 10.92def & $694.67 \mathrm{de}$ & 26.76ef & $6.99 \mathrm{~cd}$ & $12.67 \mathrm{~d}$ \\
\hline $\mathrm{T}_{8}$ & $76.13 \mathrm{de}$ & $124.72 \mathrm{ef}$ & $21.71 \mathrm{~b}$ & $22.34 \mathrm{fg}$ & $11.50 \mathrm{ef}$ & 701.50de & $27.87 \mathrm{fg}$ & $7.14 \mathrm{~cd}$ & $12.97 \mathrm{de}$ \\
\hline $\mathrm{T}_{9}$ & $73.08 \mathrm{c}$ & $117.73 c$ & $17.76 \mathrm{a}$ & $18.84 \mathrm{~cd}$ & $9.00 \mathrm{bc}$ & $563.50 \mathrm{bc}$ & $24.70 \mathrm{~cd}$ & $6.04 b c$ & $11.45 \mathrm{c}$ \\
\hline $\mathrm{T}_{10}$ & $66.17 \mathrm{~b}$ & $113.78 \mathrm{ab}$ & 14.46 & $17.00 \mathrm{ab}$ & $7.84 \mathrm{ab}$ & $495.17 \mathrm{ab}$ & $23.15 \mathrm{ab}$ & $4.99 \mathrm{ab}$ & $10.43 \mathrm{~b}$ \\
\hline $\mathrm{T}_{11}$ & $67.37 \mathrm{~b}$ & $115.21 \mathrm{~b}$ & $16.95 a$ & $18.34 \mathrm{bc}$ & $8.83 b c$ & $502.17 \mathrm{ab}$ & $24.04 b c$ & $5.39 \mathrm{ab}$ & $10.79 \mathrm{~b}$ \\
\hline $\mathrm{T}_{12}$ & $62.17 \mathrm{a}$ & $111.78 \mathrm{a}$ & 10.75 & $15.83 \mathrm{a}$ & $6.67 \mathrm{a}$ & $391.34 \mathrm{a}$ & $22.62 \mathrm{a}$ & $4.74 \mathrm{a}$ & $9.25 \mathrm{a}$ \\
\hline \multicolumn{10}{|c|}{ Treatment } \\
\hline $\mathrm{SE}( \pm)$ & 0.80 & 0.75 & 0.58 & 0.61 & 0.67 & 45.57 & 0.49 & 0.42 & 0.20 \\
\hline $\operatorname{LSD}(P=0.05)$ & 2.28 & 2.13 & 1.65 & 1.74 & 1.89 & 129.72 & 1.39 & 1.18 & 0.57 \\
\hline \multicolumn{10}{|c|}{ Practice } \\
\hline $\mathrm{SE}( \pm)$ & 0.33 & 0.31 & 0.24 & 0.25 & 0.27 & 18.60 & 0.20 & 0.17 & 0.08 \\
\hline $\operatorname{LSD}(P=0.05)$ & 0.98 & NS & NS & 0.71 & NS & NS & 0.60 & 0.49 & 0.25 \\
\hline \multicolumn{10}{|c|}{ Treatment X Practice } \\
\hline $\mathrm{SE}( \pm)$ & 1.13 & 1.06 & 0.82 & 0.86 & 0.94 & 64.45 & 0.69 & 0.59 & 0.28 \\
\hline $\operatorname{LSD}(P=0.05)$ & NS & NS & NS & NS & NS & NS & NS & NS & NS \\
\hline
\end{tabular}

Means with common letters are not significantly different at $P \leq 0.05$, according to Fisher's Protected Least Significant Difference (LSD) test using the algorithm of Studentized range test

\section{Summary}

The study thus showed that the application of 75 percent RDF along with biofertilizer and $25 \mathrm{~kg} \mathrm{ZnSO}_{4} \mathrm{ha}^{-1}$ rendered the highest growth and yield attributes of rice in SRI method of cultivation. The increasing levels of zinc in soils also increased the grain yield of rice at both the methods of cultivation.

\section{References}

1. Ali N, Pandey PC. Influence of establishment methods and integrated nitrogen management on growth, productivity and soil fertility of rice (Oryza sativa L.). The Bioscan. 2015; 10(1):391-96.

2. Bokaria K. Importance of System of Rice Intensification Method for mitigation of Arsenic in Rice. International Journal of Advanced Research. 2015; 3:1398-09.

3. Chapagain T, Yamaji E. The effects of irrigation method, age of seedling and spacing on crop performance, productivity and water-wise rice production in Japan. Paddy, Water Environment. 2010; 8:81-90.

4. Dass A, Dhar S. Irrigation management for improving productivity nutrient uptake and water-use efficiency in system of rice intensification: A review. Annals of Agricultural Research, New Series. 2014; 35:107-22.

5. Dwivedi SK, Meshram MR, Pal A, Kanwar PC. Effect of planting geometry and seedling density on growth and yield of scented rice under SRI based cultivation practices. The Bioscan. 2015; 10(1):455-58.

6. Hsu JC. Multiple Comparisons Theory and Methods. Chapman \& Hall, London. Maindonald, J.H. and Cox, N.R. (1984). Use of statistical evidence in some recent issues of DSIR agricultural journals. New Zealand Journal of Agricultural Research. 1996; 27:597-10.

7. Jnawali AD, Ojha RB, Marahatta S. Role of Azotobacter in Soil Fertility and Sustainability -A Review. Advances in Plants and Agriculture Research, 2015, 2.

8. Kabeya MJ, Shankar AG. Effect of different levels of zinc on growth and uptake ability in rice zinc contrast lines (Oryza sativa L.). Asian Journal of Plant Science and Research. 2013; 3:112-16.

9. Keram KS, Sharma BL, Sawarkar SD. Impact of Zn application on yield, quality, nutrients uptake and soil fertility in a medium deep black soil (Vertisol). International Journal of Science, Environment. 2012; 1:563-71.

10. Mahata MK, Debnath P, Ghosh SK. Critical limits of zinc in soil and rice plant grown in alluvial soils of West Bengal, India. SAARC Journal of Agriculture. 2012; 10:137-46.

11. Mohanty AK, Islam M, Kumar GAK, Kumar A. Enhancing rice (Oryza sativa) productivity through demonstrations of SRI Method of Cultivation in MidAltitude Region of Indo-Himalayan Belt of Sikkim. Indian Research Journal of Extention Education. 2014; 14:88-92.

12. Naik SK, Das DK. Relative performance of chelated zinc and zinc sulphate for lowland rice (Oryza sativa L.) Nutrient Cycling in Agroecosystem. 2008; 81:219-27.

13. Prabha AC, Thiyagarajan TM, Senthivelu M. System of Rice Intensification on growth parameters, yield attributes and yields of Rice (Oryza sativa L.). Journal of Agronomy. 2011; 10:27-33. 
14. Singh RK, Singh AN, Ram H, Prasad SR, Chauhan RK. Response of basmati (Oryza sativa L) rice varieties to system of rice intensification (SRI) and conventional methods of rice cultivation. Annals of Agricultural Research New Series. 2013; 34:50-56.

15. Sridevi V, Chellamuthu V. Influence of system of rice intensification on growth, yield and nutrient uptake of rice (Oryza sativa L.). Madras Agricultural Journal. 2012; 99:305-07.

16. Thakur P, Mukhopadhyay D, Dutta S, Majumdar K. Maximising phosphorus use efficiency in summar rice (Oryza sativa) under Terai region of West Bengal International Journal of Chemical Studies. 2019; 7(4):433-440.

17. Thakur AK, Rath S, Kumar A. Influence of System of Rice Intensification (SRI) practices on grain yield and associated physiological changes in rice plants compared with conventional flooded rice. $3^{\text {rd }}$ International Rice Congress, 8-12 Nov, Hanoi, Vietnam, 2010.

18. Thawait D, Patel AK, Kar S, Sharma M, Meshram M. Performance of transplanted scented rice (Oryza sativa L.) under SRI based cultivation practices; A sustainable method for crop production. The Bioscan. 2014; 9:53942.

19. Tzudir L, Ghosh RK. Impact of integrated nutrient management on performance of rice under System of rice Intensification (SRI). Journal of Crop and Weed. 2014; 10:331-33.

20. Weijabhandara DMDI, Dasog GS, Patil PL, Hebbar M. Effect of nutrient levels on rice (Oryza sativa L.) under System of rice intensification (SRI) and Traditional methods of cultivation. Journal of Indian Society of Soil Science. 2011; 59:67-73.

21. Yadav VK. Studies on the effect of dates of planting, plant geometry and number of seedlings per hill in hybrid rice (Oryza sativa L.), Ph.D. Agronomy Thesis submitted to Chandra Shekhar Azad University of Agriculture and technology, Kanpur (India), 2007. 